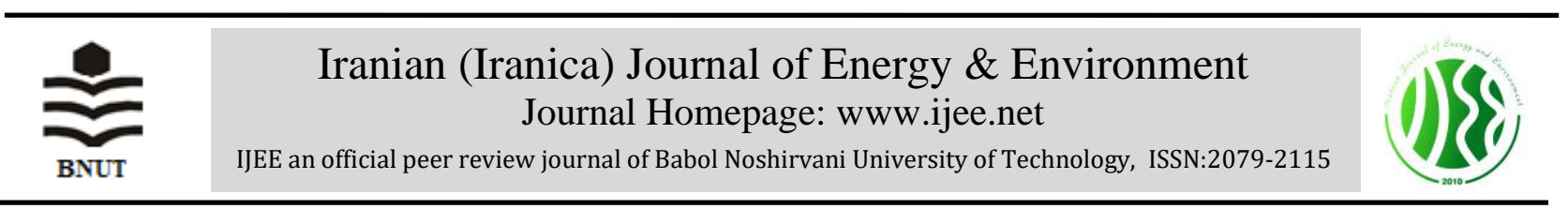

\title{
Hydraulic Analysis of Storm Water Drainage System in Alamata Town, South Tigray, Ethiopia
}

\author{
A. Zinabie ${ }^{1 *}$, B. Kebede ${ }^{2}$ \\ ${ }^{1}$ Department of Hydraulic and Water Resources Engineering, University of Gondar, Gondar, Ethiopia \\ ${ }_{2}^{2}$ School of Civil and Water Resources Engineering, Bahir Dar University (BIT), Bahir Dar, Ethiopia
}

\section{$P A P E R \quad I N F O$}

\section{Paper history:}

Received 20 December 2019

Accepted in revised form 06 February 2020

\section{Keywords:}

Bentley Flow Master

Hydrologic Analysis

Storm Water

Urbanization

\begin{abstract}
$\begin{array}{lllllllll}A & B & S & T & R & A & C & T\end{array}$
With urbanization impervious surfaces increase, drainage pattern changes, overland flow becomes speedy, flooding and environmental problems such as land degradation increases. The objective of this study is to evaluate the hydraulic performance of storm water drainage system of the study area. The drainage channels are filled with or blocked by silt and garbage, the blockage of drainage structures is due to flat areas and siltation of drainage system which leads to failures on roadways. Spatial analyses were conducted using Arc GIS, Bentley Flow master, Google Earth pro and Auto CAD software's as analytical tools. The hydrological analysis was computed by rational method. The existing depth and width of the storm water drainage channel were measured for all sub catchments of the town and used to determine the existing drainage capacity using Bentley Flow master. The existing condition drainage channel depths of sub-catchments 6,7 and 8 increased by $68.40 \%, 160.20 \%$ and $121.07 \%$; and the widths by $55.44 \%, 116.83 \%$ and $100.98 \%$, and the design discharge was also $9.29 \mathrm{~m}^{3} / \mathrm{s}, 16.47 \mathrm{~m}^{3} / \mathrm{s}$ and $9.13 \mathrm{~m}^{3} / \mathrm{s}$, respectively. Therefore, this study recommends improvement in the integration of road and drainage structure; integration of solid waste management system in order to prevent the over flowing of storm water as a result of blockage of drains; the stations of the road requires proper maintenance and suitable measures should be taken in order to make the road and storm water drainage structures serve for the intended purposes sustainably to the stakeholders.
\end{abstract}

doi: $10.5829 /$ ijee.2020.11.01.07

\section{INTRODUCTION}

Urbanization is characterized by a marked increase in built structures [1] such as streets, walkways, parking lots and rooftops creating sealed surfaces. Drainage networks are an important part of the infrastructure of any society. The main purpose of providing the drainage network is to carry away sanitary waste and storm water from a municipal area in such a way that it does not cause any public health related problems [2].

Storm water is the water generated from rainfall, it can infiltrate the ground surface and join with the ground water table or contribute to subsurface flow and the remaining portion ends up as surface runoff which ultimately joins with the streams, rivers, etc. Under natural condition, most of the storm water gets infiltrated into the soil due to higher permeability of the surface [3]. Storm water is rainwater or melted snow that runs off streets, lawns and other sites. When storm water is absorbed into soil, it is filtered and ultimately replenishes aquifers or flows into streams and rivers [4].

Storm water drainage system is designed to drain excess rain and ground water from impervious surfaces such as paved streets, car parks, parking lots, footpaths, sidewalks, and roofs [5]. In modern cities the storm water drainage system is the essential part of the urban infrastructures. Basically, the most important use of the storm water drainage system is to carry the excess rain water in the monsoon season from the roads, streets and roofs and make the city free from the problems of back flow and also from the flood. In developing countries, the factors which are affecting the storm water drainage system classified into two categories: 1) Natural 2) Human activity. Rainfall patterns, Properties of catchment areas, soil type, presence of water course, climate change etc are the natural factors. Extension of urban areas, impermeability, degradation of plant cover, lack of planning and poor management and such are the Human activities that impacts on natural storm drainage [6]. Storm water runoff can result in flood damage when large amounts of precipitation collect on the ground glide over impervious surfaces without being absorbed [7].

The absence of proper drainage negatively affects the economy of the community (car crash, delay in time or time wastage, wastage of gasoline) as well as social activities such as facilitation of trade and businesses, access to basic services,

*Corresponding Author Email: ashezinabie@gmail.com (A. Zinabie) 
safe transportation. Surface drainage involves collecting the water from the road surface, road shoulders, side slopes and adjacent areas and carrying it away via downhill slopes, roadside ditches and pipes [8].

The pattern of urbanization and modernization Ethiopia has meant increase densification along with urban infrastructure development. This has led to deforestation, use of corrugated roofs and paved surfaces. The combined effect of this results in higher raindrop intensity and consequently accelerated and concentrated runoff. Due to inadequate integration between road and urban storm water drainage, infrastructure provision and poor management significant proportion of the area is exposed to flooding hazards/risks. Appropriate design of the surface drainage system is an essential part of road design [8].

A well planned, operated and maintained storm water system should drain storm water runoff effectively during normal periods and during floods. However, with rapidly expanding cities, unanticipated problems from changing land usage, system overloading, pollution and deteriorating environment cause problems to storm water assets and contribute to its failure. These issues are more problematic in larger and older cities where replacement is costly. Alamata town is anticipated to face many of the challenges this problem poses asset manages the urban water cycle system in an integrated manner to protect, restore and enhance the storm water assets. With absence of proper drainage line along roads in the town, seasonal floods and other environmental problems are most frequently occurring especially on downstream parts of the town. This has resulted in negative impacts on sustainable urban drainage system provision and management. Thus, there is a need to study the adequacy of the existing storm water drainage system of Alamata town to handle the yearly repeating urban storm water drainage problems with overloading the drainage system and the serious consequences on the environment. In the current research, there are few sources comparing the results of evaluating hydraulic performance of storm water drainage system, even at site scale. This article seeks to bridge this gap by examining this difference. The article highlights the hydraulic performance of the existing and proposed drainage system based on the hydrological analysis. So, the study focuses on the hydraulic Analysis of storm water drainage system of the study area.

\section{MATERIALS AND METHODS}

\section{Location of study area}

Alamata town is found at a distance $600 \mathrm{~km}$ from Addis Ababa and $180 \mathrm{~km}$ from Mekelle. The Town stretches from $39^{0} 55^{\prime}$ Latitude $12^{\circ} 42^{\prime}$ 'longitude and shares borderlines on all directions with Raya Alamata Woreda. According to the Woreda Atlas; the total area coverage of the Woreda is 1050 hectare or $10.5 \mathrm{~km}^{2}$. The study area has a variable rainfall pattern with a short rainy season and a long rainy season with an average annual rainfall of $790 \mathrm{~mm}$. The Location map of the study area is described in Figure 1.

\section{Model selection}

When choosing a suitable model, it should first be considered if it is possible to use the model in respect of investments in time and money. It should then be considered whether the model gives the desired output data required for the project and if the input data required is possible to obtain within a reasonable amount of time and price. A complex model often requires more input data than a simple model, while a simple model with fewer input data instead may not be specific enough for the current study. Steps of model selection were described on Figure 2.

Based on the above model selection criteria were described on Figure 2 for this Paper Arc GIS, Google earth pro, Auto CAD and Bentley flow master were used.

A. Arc GIS: The first step in doing any kind of hydrologic modeling involves delineating streams and watersheds, and getting some basic watershed properties such as area, slope, flow length, stream network density. With the availability of digital elevation models (DEM) and GIS tools, watershed properties can be extracted by using automated procedures. The processing of DEM to delineate watersheds is referred to as terrain pre-processing. There are several tools available online for terrain pre-processing. In this thesis, Arc Hydro tools were used to process a DEM to delineate stream network and some other watershed characteristics that collectively describe the drainage patterns of a basin [9].

B. Bentley Flow Master: Bentley Flow Master is an easy-touse program that helps civil engineers/hydraulic engineer to undertake hydraulic analysis for analysis of pipes, ditches, open channels, and more andit computes flows related parameters (depth, discharge and velocity) in a given flow system i.e. open channel flow, pipe flow by using well-known formulas such as Darcy-Weisbach, Hazen-Williams and Manning's formula [10].

C. Google Earth Pro: Google earth is an additional source for deriving spatial information on drains androads.

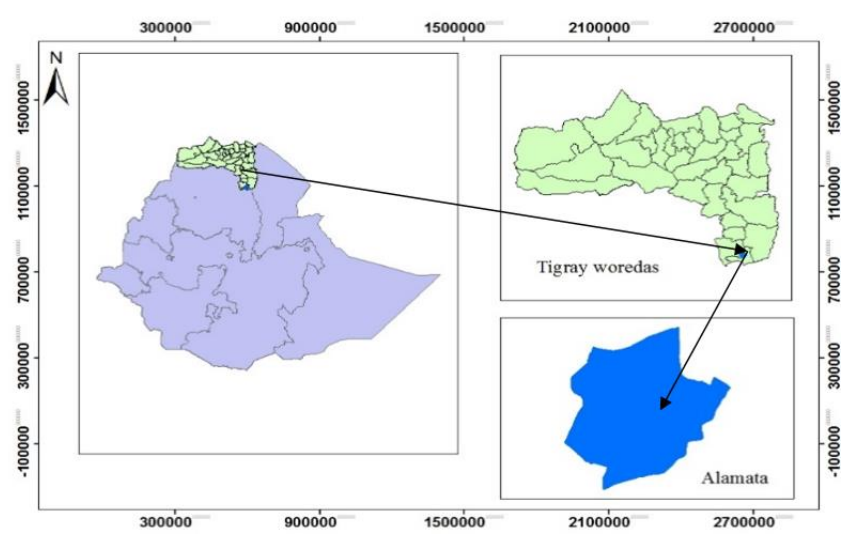

Figure 1. Location map of the study area

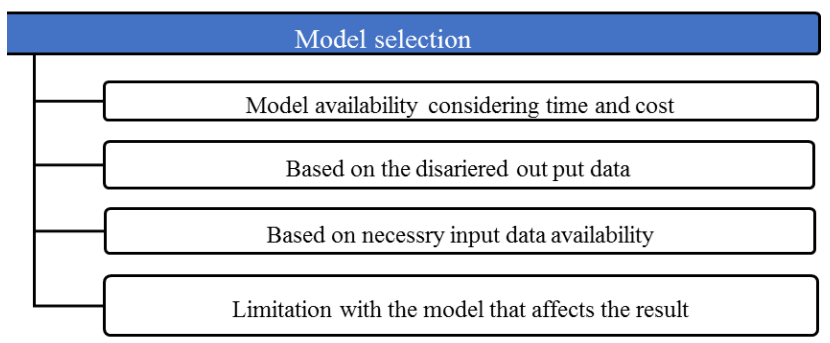

Figure 2. Steps to choose a proper model 


\section{DATA COLLECTION}

Spatial data for Alamata town were acquired from a variety of sources depending on types of data. This paper involves collection of both primary and the secondary data and was also include information from respective organizations. Primary data was collected from personal field observation/site investigation and Google earth data with the help of a base map and check list. Secondary data was collected through from different organizations, literature studies and document analysis.

\section{Digital Elevation Models (DEM)}

In this study, a Digital Elevation Model $(30 \mathrm{~m}$ x $30 \mathrm{~m}$ resolution) which was taken from Ministry of water, Irrigation and Electricity Addis Ababa Ethiopia was used.

\section{Storm sewer and drainage network}

Drainage map of Alamata town data regarding existing storm sewers along with their directions and outlets were collected from Alamata town municipality and field survey to collect channel depth and width of the drainage network.

\section{Land use maps}

Land use/Land cover maps of Alamata town during 2018 were collected from Ministry of Agriculture, Addis Ababa, Ethiopia.

\section{Metrological data}

Metrological Data was collected from National Meteorological Service Agency Addis Ababa, Ethiopia.

\section{DATA ANALYSIS}

For accomplishing the objectives of the study and to answering the research questions, the collected raw data was edited, coded, classified, and tabulated in order to make it ready for analysis. Information from primary and secondary sources was analyzed by using qualitative and quantitative methods. Data that have quantitative nature such as average and percentage was computed with Microsoft Excel. Furthermore, spatial analyses were conducted using Arc GIS, Bentley flow Master, Google earth pro and Auto CAD software as analytical tools. Figure 3 is described the methodology for determination of the actual and design discharge of Alamata town to evaluate the adequacy of existing storm water drainage system.

\section{Hydraulic and hydrological analysis}

\section{Meteorological data availability In order to apply} flood estimation models for peak discharge computation using available rainfall data, the rainfall depth-durationfrequency relationship is required. Available rainfall data on these stations has been collected and analyzed using two methods of distribution analysis namely Log Pearson-III and Gumbel's Methods. Due to the rain gage station in the study area is one the outlier test is appropriate to check the quality of the data.

Estimating missing rainfall data

Due to the absence of observer or instrumental failure rainfall data record occasionally are incomplete. In such a case one can estimate the missing data by using the nearest station rainfall data. There are different approaches for estimating missing rainfall data varying with and based on the effect of orography on rainfall, distance between the rainfall stations and the variation of rainfall amount recorded on the stations.

Among different method Normal ratio method was one of them which was recommended to estimate missing rainfall data in regions where annual rainfall between stations differ by more than $10 \%$ [11].

$$
P Z=\frac{1}{3}\left(P 1 \frac{N Z}{N 1}+P 2 \frac{N Z}{N 2}+P 3 \frac{N Z}{N 3}\right)
$$

where:

$\mathrm{P}_{\mathrm{z}}$ :missing rainfall data (daily, monthly or yearly)

$\mathrm{P}_{1}, \mathrm{P}_{2}$ and $\mathrm{P}_{3}$ : rainfall data at nearest different station (daily, monthly or yearly)

$\mathrm{N}_{\mathrm{z}}$ : mean annual rainfall at missed station

$\mathrm{N}_{1}, \mathrm{~N}_{2}$, and $\mathrm{N}_{3}$ : mean annual rainfall at different nearest station.

Check the quality of data Check on outliers has been undertaken on the recoded rainfall data to identify any low or high outliers. Outliers are data points, which depart significantly from the trend of the remaining data.The outlier test is done to check whether the adopted data is within the limited range or not. The daily heaviest rainfall data of Alamata meteorological station from 1995 to 2019 was taken for the design. Hence, 25 years of daily heaviest rainfall data is available. These data was also checked for its consistency by higher and lower outlier testes using the equations [11] described in Table 1.

\section{Test for higher outlier}

$$
\text { Higher outlier: } Y H=Y a v g+K n * \delta n-1
$$

where:

Yavg: mean of data in log unity

$\mathrm{Kn}$ : from Table 2 for sample size $\mathrm{N}$

$\boldsymbol{\delta} \boldsymbol{n}-\mathbf{1}$ : standard deviation from Table 1.

Higher outlier test $=\mathbf{1 0}^{\boldsymbol{Y H}}$

For data Yavg=1.719, N=25, $\delta \mathrm{n}-1=0.101$ from Table 1 and $\mathrm{Kn}=2.563$ from Table 2 .

Higher outlier test $Y H=\mathrm{Y}-+\mathrm{Kn} * \delta \mathrm{n}-1=1.719+$ $2.563 * 0.101=1.966$

Higher outlier test $=10^{Y H}=10^{1.966}=92.533$

The highest recorded value from meteorological station is $(80.2 \mathrm{~mm})$ as described in Table 1 which was less than the higher outlier test $(92.5337 \mathrm{~mm})$. Therefore, no higher outlier data eliminated.

\section{Test for lower outlier}

$$
\text { lower outlier: } Y L=Y a v g-K n * \delta n-1
$$

Lower outlier $=10^{\mathrm{YL}}$

$\mathrm{YL}=1.7119-2.563 * 0.101=1.454$

$\mathrm{YL}=10^{1.454}=28.43$

The lower recorded value from meteorological station is $(27.7$ $\mathrm{mm}$ ) as described in Table 1 which was less than the lower outlier test $(28.425 \mathrm{~mm})$. Therefore, the lowest value from recorded data $(27.7 \mathrm{~mm})$ was excluded from the hydrological analysis. 


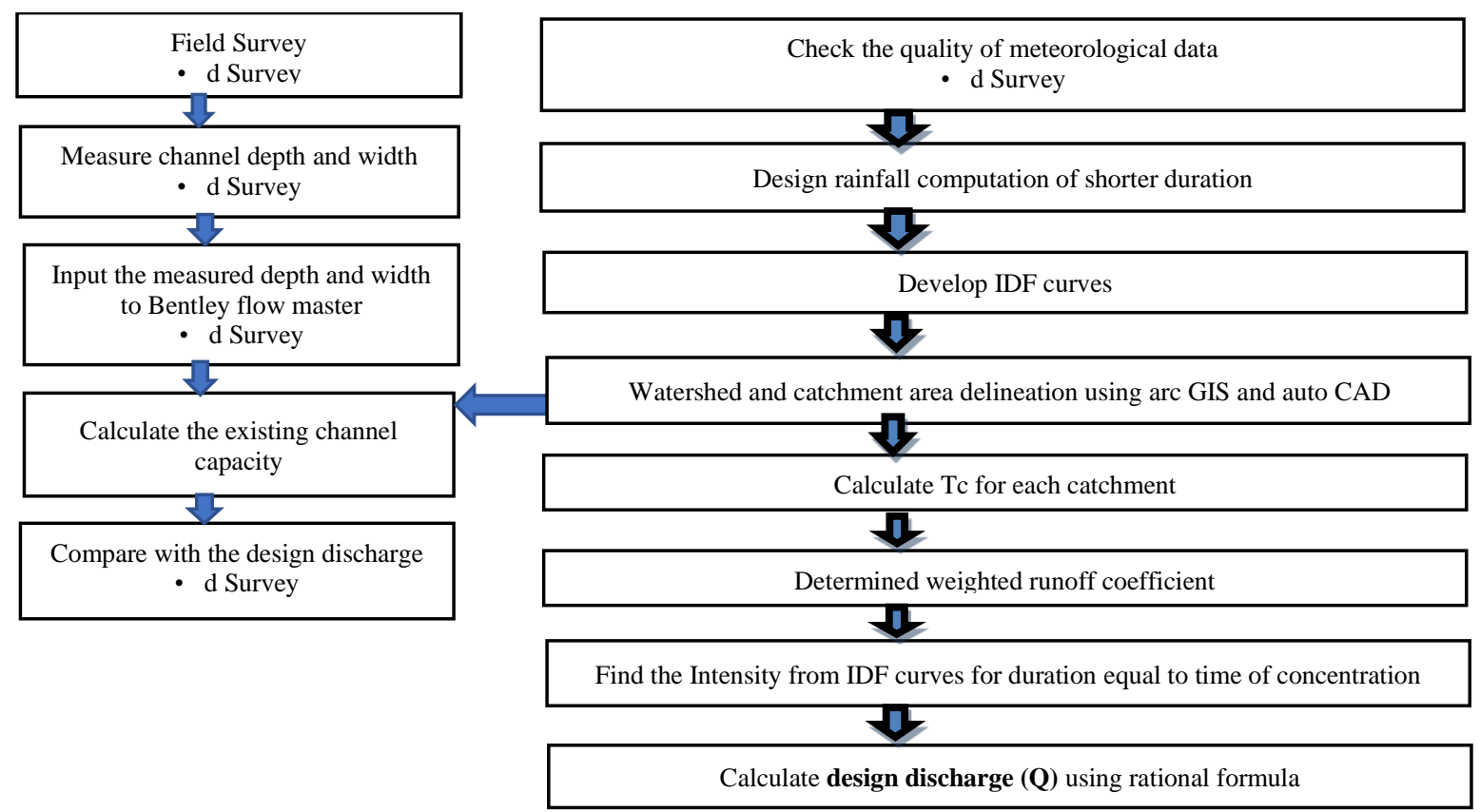

Figure 3. Determination of the actual and design discharge of Alamata town to evaluate the adequacy of existing storm water drainage system

TABLE 1. Max rainfall data from 1995-2019 and its statistical calculation

\begin{tabular}{|c|c|c|c|c|c|c|c|}
\hline S. No & Year & Max Daily Rainfall & Descending Order & Rank & Logarithmic Value/Yo/ & New Rainfall(X) & $\log (X)$ \\
\hline 1 & 1995 & 55.4 & 80.2 & 1 & 1.904 & 80.2 & 1.904 \\
\hline 2 & 1996 & 39 & 73.7 & 2 & 1.867 & 73.7 & 1.867 \\
\hline 3 & 1997 & 50 & 73.7 & 3 & 1.867 & 73.7 & 1.867 \\
\hline 4 & 1998 & 46 & 73.7 & 4 & 1.867 & 73.7 & 1.867 \\
\hline 5 & 1999 & 62 & 66.2 & 5 & 1.821 & 66.2 & 1.821 \\
\hline 6 & 2000 & 58.5 & 64.7 & 6 & 1.811 & 64.7 & 1.811 \\
\hline 7 & 2001 & 66.2 & 62 & 7 & 1.792 & 62 & 1.792 \\
\hline 8 & 2002 & 44.5 & 62 & 8 & 1.792 & 62 & 1.792 \\
\hline 9 & 2003 & 64.7 & 58.5 & 9 & 1.767 & 58.5 & 1.767 \\
\hline 10 & 2004 & 53.1 & 58 & 10 & 1.763 & 58 & 1.763 \\
\hline 11 & 2005 & 55.2 & 55.4 & 11 & 1.744 & 55.4 & 1.744 \\
\hline 12 & 2006 & 48 & 55.2 & 12 & 1.742 & 55.2 & 1.742 \\
\hline 13 & 2007 & 58 & 53.1 & 13 & 1.725 & 53.1 & 1.725 \\
\hline 14 & 2008 & 37.3 & 53 & 14 & 1.724 & 53 & 1.724 \\
\hline 15 & 2009 & 62 & 50 & 15 & 1.699 & 50 & 1.699 \\
\hline 16 & 2010 & 33.3 & 48 & 16 & 1.681 & 48 & 1.681 \\
\hline 17 & 2011 & 27.7 & 47.8 & 17 & 1.679 & 47.8 & 1.679 \\
\hline 18 & 2012 & 47.8 & 46 & 18 & 1.663 & 46 & 1.663 \\
\hline 19 & 2013 & 80.2 & 45.3 & 19 & 1.656 & 45.3 & 1.656 \\
\hline 20 & 2014 & 45.3 & 44.5 & 20 & 1.648 & 44.5 & 1.648 \\
\hline 21 & 2015 & 73.7 & 42.7 & 21 & 1.63 & 42.7 & 1.63 \\
\hline 22 & 2016 & 73.7 & 39 & 22 & 1.591 & 39 & 1.591 \\
\hline 23 & 2017 & 73.7 & 37.3 & 23 & 1.572 & 37.3 & 1.572 \\
\hline 24 & 2018 & 53 & 33.3 & 24 & 1.522 & 33.3 & 1.522 \\
\hline 25 & 2019 & 42.7 & 27.7 & 25 & 1.442 & & \\
\hline \multicolumn{3}{|l|}{ Mean } & 51.556 & & 1.719 & 52.725 & 1.73 \\
\hline \multicolumn{3}{|c|}{ Standard deviation } & 11.257 & & 0.101 & 10.523 & 0.101 \\
\hline \multicolumn{3}{|c|}{ Skewnesscoefficient } & & & -0.163 & & -0.163 \\
\hline
\end{tabular}




\section{Checking data reliability}

For data $\mathrm{N}=24$ and $\delta \mathrm{n}-1=10.52$ Mean $\left(\mathrm{X}^{-}\right)=52.556$ from Table 1.

Standard error of mean $(\delta \mathrm{n}-1)=\frac{10.52}{\sqrt{24}}=2.15$

Relative standard $(\delta \mathrm{n})=\frac{\boldsymbol{\delta} \mathbf{n}-\mathbf{1}}{X-} * 100=\frac{2.145}{52.556} * 100=4.09 \%<$ $10 \%$ hence the data series could be regarded as reliable.

\section{Design rainfall computation of shorter duration}

These rainfall analyses and processing is aimed at determination of appropriate Intensity-Duration Frequency relationship. Extreme rainfall depth at town station for different return periods was determined using Log Pearson Type III distributions and Gumbel method analysis [11]. The rainfall depths obtained from gauging station are of $24 \mathrm{~h}$ duration depth. Design and analysis of drainage structures require rainfall intensity duration relationship of shorter duration. Because rainfall data of shorter duration is an available appropriate IDF derivation for shorter duration is required [12] suggests the following equation.

\section{Log Pearson Type III distributions}

$$
Y T=Y a v g+K T * S y
$$

where:

YT: Log XT -logarithm of Rainfall depth (X T) at return period $T$ years $[\mathrm{mm}]$

Yavg: Mean value of logarithmic rainfall data (daily) [mm]

Sy: Standard deviation [mm] (Table 3).

\section{Gumbel method analysis}

$$
\begin{aligned}
& X T=\text { Xmean }+K * S y \\
& y=\frac{\sqrt{\Sigma y^{2}-1 / n\left(\Sigma y^{2}\right)}}{n-1}
\end{aligned}
$$

Sy: Stander deviations of sample size N
$\mathrm{K}$ : frequency factors expressed as $K=\frac{Y t-Y n}{S n}$, Yn and $\mathrm{Sn}$ reduced standard deviations, as sample $\mathrm{N}$ in Table 4 [13].

\section{INTENSITY-DURATION-FREQUENCY (IDF) CURVES}

The IDF relationships are used when designing drainage works for any engineering project, and allow the engineer to design safe and economical flood control measures.

The rainfall depths obtained from gauging station are of $24 \mathrm{~h}$ duration depth. Design and analysis of drainage structures require rainfall intensity duration relationship of shorter duration. Because rainfall data of shorter duration is unavailable, appropriate IDF derivation for shorter duration is required.

$$
R R t=\frac{t}{24}\left[\frac{(b+24)^{n}}{(b+t)^{n}}\right]
$$

where:

RRt: Rainfall depth ratio Rt:R24

$\mathrm{Rt}$ : Rainfall depth in a given duration $\mathrm{t}$

$\mathrm{R}_{24}: 24 \mathrm{~h}$ rainfall depth

Coefficients $b=0.3$ and $n=0.78-1.09$

Substituting Intensity $(\mathrm{mm} / \mathrm{h})$ in the above equation:

$$
I t=\frac{R t}{t}=\frac{R 24}{24}\left[\frac{(b+24)^{n}}{(b+t)^{n}}\right]
$$

The methods employed to develop IDF curve for the shorter duration events using the above equations are as follows. Among many frequencies analyses Log Pearson type III better $\mathrm{R}^{2}$ value, so for this paper Log Pearson type III distribution was selected. Using the trend line equation obtained from Log Pearson type III distribution method of frequency analysis, that is $y=0.2715 X+59.841$ where $y$ is

\begin{tabular}{|c|c|c|c|c|c|c|c|}
\hline \multirow{2}{*}{ Sample size } & \multirow{2}{*}{ Kn } & \multirow{2}{*}{ Sample size } & \multicolumn{2}{|r|}{ Sample size } & \multirow{2}{*}{$\begin{array}{c}\text { Value } \\
\text { Kn }\end{array}$} & \multirow{2}{*}{$\begin{array}{c}\text { Sample size } \\
\mathrm{N}\end{array}$} & \multirow{2}{*}{$\begin{array}{c}\text { Value } \\
\text { Kn }\end{array}$} \\
\hline & & & Kn & $\mathbf{N}$ & & & \\
\hline 10 & 2.036 & 24 & 2.467 & 38 & 2.661 & 60 & 2.837 \\
\hline 11 & 2.088 & 25 & 2.467 & 39 & 2.671 & 65 & 2.866 \\
\hline 12 & 2.134 & 26 & 2.502 & 40 & 2.682 & 70 & 2.893 \\
\hline 13 & 2.175 & 27 & 2.519 & 41 & 2.692 & 75 & 2.917 \\
\hline 14 & 2.213 & 28 & 2.534 & 42 & 2.7 & 80 & 2.94 \\
\hline 15 & 2.247 & 29 & 2.549 & 43 & 2.71 & 85 & 2.917 \\
\hline 16 & 2.309 & 30 & 2.563 & 44 & 2.719 & 90 & 2.961 \\
\hline 17 & 2.309 & 31 & 2.577 & 45 & 2.727 & 95 & 2.981 \\
\hline 18 & 2.361 & 32 & 2.591 & 46 & 2.736 & 100 & 3 \\
\hline 19 & 2.385 & 33 & 2.604 & 47 & 2.744 & 110 & 3.017 \\
\hline 20 & 2.408 & 34 & 2.619 & 48 & 2.744 & 120 & 3.078 \\
\hline 21 & 2.408 & 35 & 2.628 & 49 & 2.753 & 130 & 3.107 \\
\hline 22 & 2.429 & 36 & 2.639 & 50 & 2.76 & 140 & 3.214 \\
\hline 23 & 2.448 & 37 & 2.65 & 55 & 2.768 & & \\
\hline
\end{tabular}
24-hour rainfall depth $\left(\mathrm{R}_{24}\right)$ of a return period $\mathrm{x}$ under consideration, $\mathrm{R}_{24}$ is calculated for $2,5,10,25,50$ - and 100year return period.

TABLE 2. Outlier test Kn value 
TABLE 3. Yearly extreme series and frequency analysis Log-Pearson Type III distribution

\begin{tabular}{|c|c|c|c|c|c|}
\hline Return period(T) & $\mathbf{X}^{-}$ & $\delta n-1$ & KT & $Y T=X^{-}+K T * \delta n-1$ & $\mathrm{XT}=10^{\mathrm{YT}}$ \\
\hline 2 & 1.711 & 0.0854 & -0.017 & 1.710 & 51.233 \\
\hline 5 & & & 0.836 & 1.782 & 60.587 \\
\hline 10 & & & 1.292 & 1.821 & 66.269 \\
\hline 25 & & & 1.751 & 1.861 & 72.527 \\
\hline 50 & & & 2.054 & 1.886 & 76.979 \\
\hline 100 & & & 2.472 & 1.922 & 83.572 \\
\hline
\end{tabular}

TABLE 4. Yearly extreme series and frequency analysis calculations Gumbel distribution

\begin{tabular}{lccccccc}
\hline Return Period (T) & $\mathbf{X}^{-}$ & $\mathbf{\delta n - 1}$ & $\mathbf{Y n}$ & $\mathbf{S y}$ & $\mathbf{Y T}$ & \multicolumn{1}{c}{ KT } & $\mathbf{X T}=\mathbf{X}+\mathbf{K T} * \mathbf{S y}$ \\
\hline 2 & 52.3793 & 10.498 & 0.5353 & 1.1086 & 0.3665 & -0.1522 & 50.7808 \\
5 & & & & 1.4999 & 0.8701 & 61.5147 \\
10 & & & & 2.2503 & 1.5470 & 68.6214 \\
25 & & & 3.1985 & 2.4023 & 77.6008 \\
50 & & & & 3.9019 & 3.0368 & 84.2623 \\
100 & & & & 4.6001 & 3.6666 & 90.8746 \\
\hline
\end{tabular}

\section{CATCHMENT AREA AND STREAM NETWORK DELINEATION USING ARC GIS AND ARC SWAT}

This tool allows the user to delineate sub watersheds based on an automatic procedure using Digital Elevation Model (DEM $30 \mathrm{~m} \times 30 \mathrm{~m}$ ) data. User specified parameters provide limits that influence the size and number of subwatersheds created. In addition, users have the option of importing pre-defined watershed boundaries and an associated stream network. Figure 4 descirbed catchment delineation of Alamata Town. Procedures to delineate watershed using Arc SWAT

- Load the DEM (30mx30m)

- Define the working area (Mask)

- Load the stream network to be used for the delineation

- Preprocess the DEM

- Specify the minimum sub-watershed area (critical source area)

- Review and edit the stream network points

- Run the calculation of the subbasin parameters

\section{HYDROLOGICAL EQUATIONS FOR DETERMINING PEAK RUNOFF \\ Rational method}

This method is widely used for peak discharge determination from smaller catchments (less than 50 ha or $0.5 \mathrm{Km}^{2}$ area) as recommended by ERA drainage design manual. The equation of rational formula is function of catchment area, runoff coefficient and time of concentration. The equation is expressed as:

$$
Q=0.00278 C I A
$$

where:

Q: Discharge at outlet $\left(\mathrm{m}^{3} / \mathrm{s}\right)$

C: Runoff Coefficient

I: Maximum probable rainfall Intensity $(\mathrm{mm} / \mathrm{h})$

$\mathrm{A}=$ Catchment Area (hectares)

\section{Runoff coefficient}

A weightage method is employed to obtain the representative runoff coefficient i.e. the individual areas multiplied by their specific runoff coefficient and their values added together and divided by the cumulative area.

$$
C_{\text {weighted }}=\frac{\sum(A i * C i)}{A T}
$$

where:

$\mathrm{Ci}$ : Runoff coefficient for a given hydrologic soil group area Ai: Area under each hydrologic soil group

AT: Total catchment area considered of town

\section{Time of concentration}

The time of concentration is the time required for the rain water to flow over the ground surface from the farthest point in the drainage basin and reach the point under consideration (point of entry in the drain) [14].

Sheet flow time It usually occurs in the headwater of the streams (usually for the first 100mrun), but from topographic map obtained $100 \mathrm{~m}$ Sheet flow, natural range and short grass slope of $0.015 \mathrm{~m} / \mathrm{m}$, and length of $100 \mathrm{~m}$ and

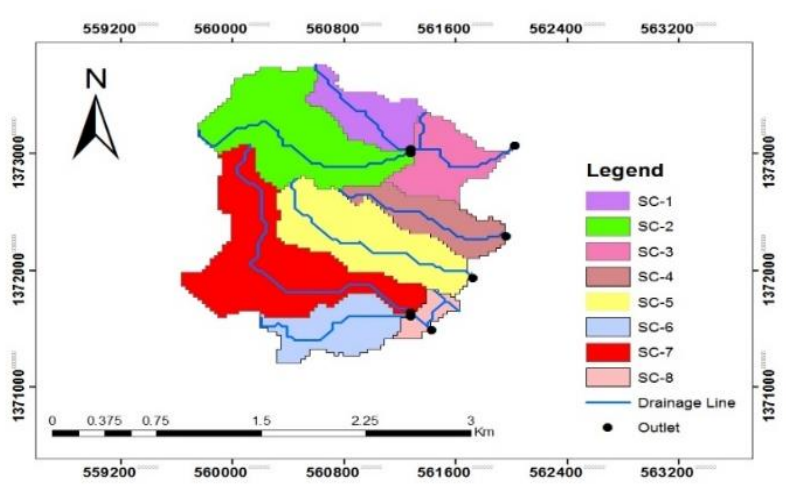

Figure 4. Catchment delineation of Alamata town 
Manning's roughness coefficient is 0.015 . The 2-year, 24hour rainfall depth is calculated to be $33.466 \mathrm{~mm}$. Hence, from Equation (11) travel time for sheet flow is determined as:

$$
T t 1=\left\{\left(\frac{0.091 *(n * L)^{0.8}}{(P 2)^{0.5}+S^{0.4}}\right)\right\}
$$

where:

Tt: travel time, hr

$\mathrm{n}$ : Manning's roughness coefficient

L: flow length, $m$

$\mathrm{P}_{2}$ : 2-year, 24-hour rainfall, $\mathrm{mm}$

$\mathrm{S}$ : slope of hydraulic grade line (land slope), $\mathrm{m} / \mathrm{m}$ based on topographic map

Open channels flow For channel flow, natural stream channel, winding with weeds and pools, slope is $0.02 \mathrm{~m} / \mathrm{m}$ and length is $3394 \mathrm{~m}$. By direct measuring the average bottom width of the stream channel is $1.2 \mathrm{~m}$.

$$
\text { Velocity through the channel: } V=\frac{R^{\frac{2}{3}} * S^{\frac{1}{2}}}{n}
$$

The time of concentration is the sum of all $\mathrm{Tt}$ values for the various consecutive flow segments.

$$
\text { Total Time of Concentration: }(T c)=T t 1+T t 2
$$

By the same processes, Time of concentration for the other catchments is determined in Table 5.

\section{Capacity of existing drainage structures}

The current conditions of hydraulic calculation are performed and evaluated by collecting the data of existing storm water drainage structure using field survey. The existing depth and width of the storm water drainage channel were measured for all sub catchments of the town and used to determine the existing drainage capacity using Bentley Flow master.

Adequacy of existing drainage structures and its proposed Based on the hydraulic calculation of the result drainage capacity of existing system were checked to compare with proposed discharge this process also done first by determining the peak discharge for each existing catchment from the measured depth and width of the storm water drainage channel for all sub catchments of the town. The design capacity of the sub catchments of the town was calculated by taking the intensity for 25-year return period from the IDF was determined by rational formula. This discharge was also compared with existing discharge of the town was determined from the measured depth and width of the storm water drainage channel for all sub catchments of the town. Then for this Existing and Design discharge drainage size (channel depth and width) was determine.

\section{Drainage size determination for proposed}

By used manning equation determined the size of the drainage channel based on the parameter for most economical rectangular channel for the proposed condition.

$$
Q=\frac{A * R \frac{2}{3} * S \frac{1}{2}}{n}
$$

Area of rectangular channel: $A=b * y$

For most economical rectangular channel: $b=2 * y$

Area of rectangular channel $A=2 y^{2} P=2 y+2 y=4 y$ and $=R=\frac{2 y^{2}}{4 y}=0.5 y, \frac{Q * n}{S^{\frac{1}{2}}}=y^{\frac{8}{3}} y=\left(\frac{Q * n}{S^{1 / 2}}\right)^{8 / 3}$

$\%$ Additional Depth $=$

$\left(\frac{\text { Proposed Depth-Existing Depth }}{\text { Existing Depth }}\right) * 100$

$\%$ Additional width $=$

$\left(\frac{\text { Proposed Width-Existing Width }}{\text { Existingwidth }}\right) * 100$

\section{RESULTS AND DISCUSSION}

Topography and impervious surface

As illustrated in the map (Figure 5) the upper part of the watershed is characterized by steep type of slope $(>20 \%)$.

\begin{tabular}{|c|c|c|c|c|c|}
\hline Sub-catchment & Sheet flow timeTC ${ }_{1}(\mathrm{Hr})$ & Open Channels Flow $\mathrm{TC}_{2}(\mathrm{Hr})$ & Total Te(Hr) & Total Te(min) & Total Te(hr) \\
\hline SC-1 & 0.1 & 0.07 & 0.18 & 10.52 & 0.18 \\
\hline SC_2 & 0.12 & 0.14 & 0.26 & 15.54 & 0.26 \\
\hline SC-3 & 0.12 & 0.15 & 0.27 & 16.24 & 0.27 \\
\hline SC-4 & 0.11 & 0.12 & 0.23 & 13.81 & 0.23 \\
\hline SC-5 & 0.12 & 0.15 & 0.27 & 16.02 & 0.27 \\
\hline SC-6 & 0.11 & 0.1 & 0.21 & 12.5 & 0.21 \\
\hline SC-7 & 0.12 & 0.22 & 0.34 & 20.19 & 0.34 \\
\hline SC-8 & 0.13 & 0.04 & 0.17 & 10.34 & 0.17 \\
\hline
\end{tabular}

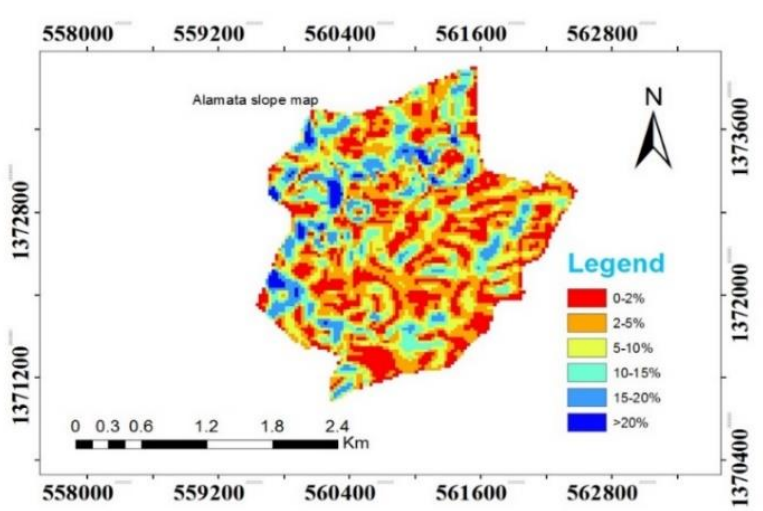

Figure 5. Slope map of Alamata town

TABLE 5. Time of concentration result in drainage system 
Consequently, the middle part of the watershed is categorized as a flat $(0-5 \%)$ kind of topography which covers. The characteristic of the slope has impact on the velocity and infiltration rate of storm water. Storm water from the upper part of the watershed flows with high velocity causing fragmentation of cobblestone and damaged the drainage channel. According to site observation, the drainage system provided along the local streets of this area doesn't consider this slope character of the area. Therefore, storm water in this area flows with high velocity in the provided drainage systems. Figure 5 described Slope map of Alamata town with the effect of topography.

\section{HYDROLOGICAL AND HYDRAULIC ANALYSIS}

\section{Intensity-duration-frequency (IDF) curves}

As described in the methodology the resulting IDF curve was used the daily maximum rainfall from Ethiopian Meteorological Agency rainfall gauge located in Alamata town, 24-hour rainfall data of 25 years was calculated using Log Pearson type- III distribution method because it has better $\mathrm{R}^{2}$ values as shown in Figure 6 (and also see Table 6).

Rainfall intensity for the design storm was used to calculate peak runoff rate from a drainage area for the design of storm water structures using the rational method. For this study IDF curve from ERA could be used, however, we developed IDF curve using the local rainfall data and compared with IDF curve from ERA drainage design manual and found rainfall intensity values much different from ERA design manual. The difference in the two intensity values as described in Figure 7 (and also see Table 7). is due to differences in the data used to develop the IDF curve in the two studies.

\section{Catchment area and stream network delineation using arc} GIS and arc SWAT

As described in the methodology part to delineate sub watersheds based on an automatic procedure using Digital Elevation Model of $(30 \mathrm{~m} \times 30 \mathrm{~m})$. Figure 4 discirbed Catchment delineation of Alamata Town.

\section{Time of concentration}

Sheet flow time It usually occurs in the headwater of the streams (usually for the first $100 \mathrm{~m}$ run). As described in the methodology sheet flow time was calculated as follows:

$$
T t 1=\left\{\frac{0.091 *(0.015 * 100)^{0.8}}{(33.466)^{0.4}+0.02^{0.4}}\right\}=0.10 h
$$
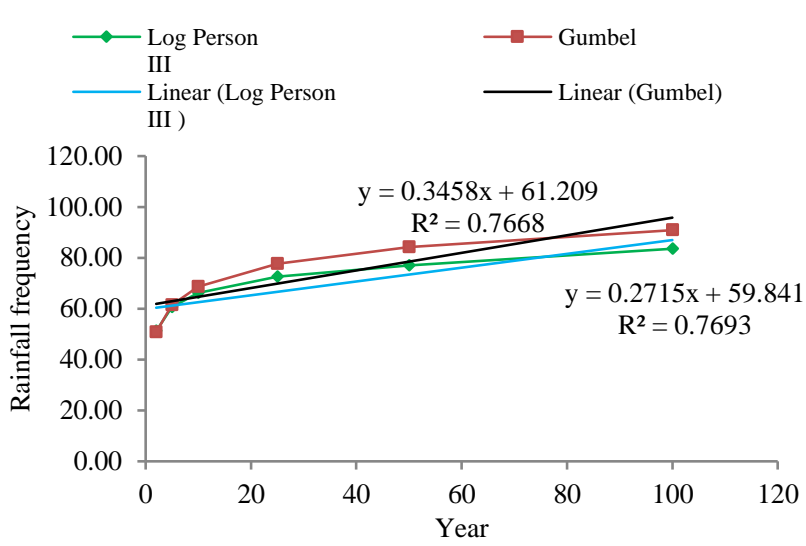

Figure 6. Plots of frequency analysis results based on Table 6 calculated design point rainfall

TABLE 6. Design point rainfall and return period

\begin{tabular}{|c|c|c|}
\hline \multirow{2}{*}{$\begin{array}{c}\text { Return Period } \\
\text { (Year })\end{array}$} & \multicolumn{2}{|c|}{ Design Point Rainfall } \\
\hline & Log Person III & Gumbel \\
\hline 2 & 51.23 & 50.78 \\
\hline 5 & 60.59 & 61.51 \\
\hline 10 & 66.27 & 68.62 \\
\hline 25 & 72.53 & 77.6 \\
\hline 50 & 76.98 & 84.26 \\
\hline 100 & 83.57 & 90.87 \\
\hline
\end{tabular}

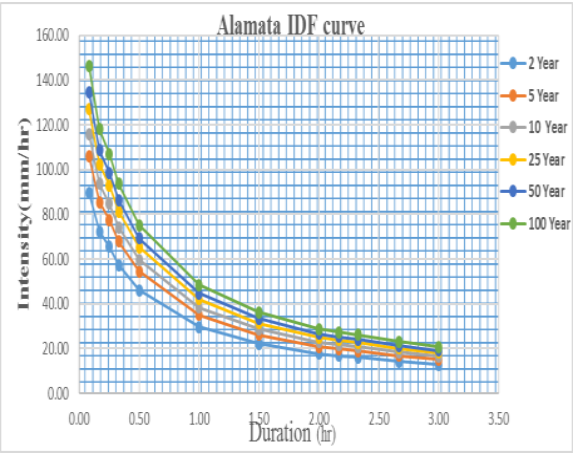

(a)

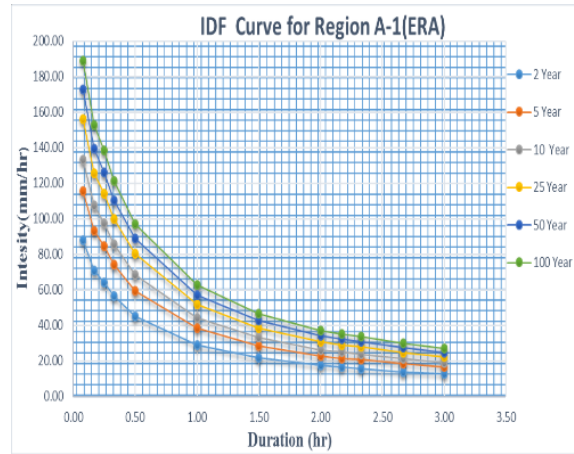

(b)

Figure 7. (a) Alamata IDF curve, (b) IDF curve for region A-1(ERA,2013) based on calculated values on Table 7 
TABLE 7. Comparison of IDF curve results for Alamat with IDF curve from ERA for station(A1)

\begin{tabular}{lcccccccccccc}
\hline Duration & ERA & SELF & ERA & SELF & ERA & SELF & ERA & SELF & ERA & SELF & ERA & SELF \\
(mint) & T-2 & T-2 & T-5 & T-5 & T-10 & T-10 & T-25 & T-25 & T-50 & T-50 & T-100 & T-100 \\
\hline 5 & 89.7 & 88.0 & 115.5 & 106.0 & 133.5 & 116.0 & 156.0 & 126.9 & 172.6 & 134.7 & 189.1 & 146.3 \\
10 & 72.3 & 71.0 & 93.2 & 85.5 & 107.7 & 93.6 & 125.8 & 102.4 & 139.2 & 108.7 & 152.6 & 118.0 \\
15 & 65.6 & 64.4 & 84.5 & 77.6 & 97.6 & 84.8 & 114.1 & 92.8 & 126.2 & 98.5 & 138.3 & 107.0 \\
20 & 57.4 & 56.4 & 74.0 & 67.9 & 85.5 & 74.3 & 99.9 & 81.3 & 110.6 & 86.3 & 121.2 & 93.7 \\
30 & 46.1 & 45.3 & 59.4 & 54.5 & 68.7 & 59.6 & 80.2 & 65.3 & 88.8 & 69.3 & 97.3 & 75.2 \\
60 & 29.7 & 29.2 & 38.3 & 35.1 & 44.2 & 38.4 & 51.7 & 42.1 & 57.2 & 44.6 & 62.7 & 48.5 \\
90 & 22.2 & 21.8 & 28.6 & 26.3 & 33.1 & 28.7 & 38.6 & 31.4 & 42.7 & 33.4 & 46.8 & 36.2 \\
120 & 17.7 & 17.4 & 22.8 & 20.9 & 26.3 & 22.9 & 30.8 & 25.0 & 34.0 & 26.6 & 37.3 & 28.8 \\
130 & 16.8 & 16.5 & 21.6 & 19.8 & 25.0 & 21.7 & 29.2 & 23.7 & 32.3 & 25.2 & 35.4 & 27.3 \\
140 & 16.1 & 15.8 & 20.7 & 19.0 & 23.9 & 20.8 & 27.9 & 22.7 & 30.9 & 24.1 & 33.9 & 26.2 \\
160 & 14.2 & 13.9 & 18.3 & 16.8 & 21.1 & 18.4 & 24.7 & 20.1 & 27.3 & 21.3 & 29.9 & 23.2 \\
180 & 12.8 & 12.6 & 16.5 & 15.1 & 19.1 & 16.6 & 22.3 & 18.1 & 24.7 & 19.2 & 27.0 & 20.9 \\
\hline
\end{tabular}

Open channels flow For channel flow, natural stream channel, winding with weeds and pools, slope is $0.02 \mathrm{~m} / \mathrm{m}$ and length is $3394 \mathrm{~m}$.

Velocity through the channel $\mathrm{V}=\frac{\mathrm{R}^{\frac{2}{3}} * \mathrm{~S}^{\frac{1}{2}}}{\mathrm{n}} \mathrm{V}=\frac{0.3^{\frac{2}{3}} * 0.2^{\frac{1}{2}}}{0.015}=$ $4.23 \mathrm{~m} / \mathrm{s}$

$\mathrm{Tt} 2=\frac{\mathrm{L}}{3600 * \mathrm{~V}}=\frac{1085}{3600 * 4.23}=0.071 \mathrm{~h}$

The time of concentration is the sum of all $\mathrm{Tt}$ values for the various consecutive flow segments. Total Time of Concentration $(T c)=T t 1+T t 2=0.10 h+0.07 h=0.17 h$ By the same processes, Time of concentration for the other catchments is determined in Table 5.

\section{HYDRAULIC ANALYSIS}

\section{Adequacy of existing drainage structures}

The existing depth and width of the storm water drainage channel were measured for all sub catchments of the town and used to determine the existing drainage capacity using Bentley Flow master described in Table 2 below for all the respective sub catchments and Figure 8 also described Cross section for Rectangular Channel Sub- Catchment -1 .

Adequacy of existing drainage structures and its proposed Based on the hydraulic calculation of the result drainage

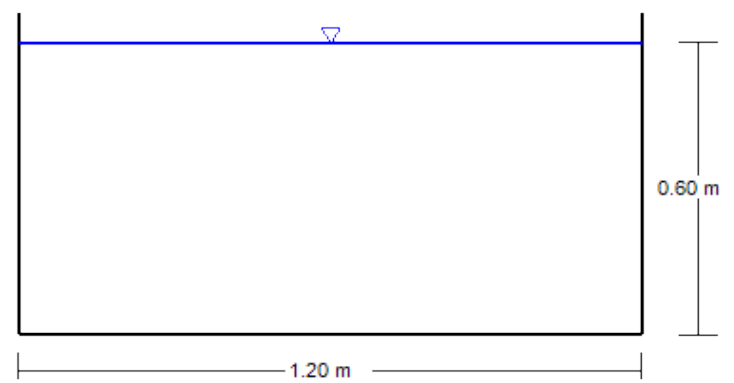

Figure 8. Cross section for rectangular channel sub-catchment-1 capacity of existing system were checked and presented in Table 8 to compare with proposed discharge as described in the methodology part. The design capacity of the sub catchments of the town was calculated by taking the intensity for 25-year return period from the IDF was determined using rational formula.

\section{Drainage size determination for proposed}

As described in the methodology by used manning equation (Equation (14)) determined the size of the drainage channel based on the parameters.

Area of rectangular channel $A=b * y$ for most economical rectangular channel $b=2 * y$

Area of rectangular channel $=2 y^{2} P=2 y+2 y=4 y$ and $=R=\frac{2 y^{2}}{4 y}=0.5 y$

$\frac{Q * n}{S^{\frac{1}{2}}}=y^{\frac{8}{3}} y=\left(\frac{Q * n}{S^{1 / 2}}\right)^{8 / 3}$

$y=\left(\frac{8.69 * 0.015}{0.02^{\frac{1}{2}}}\right)^{\frac{8}{3}}=0.97 \mathrm{~m}$ and width $\mathrm{b}=2 * \mathrm{y}=2 *$

$0.97=1.94 \mathrm{~m}$

$\%$ Additional Depth $=\left(\frac{0.97-0.60}{0.60}\right) * 100=61.58 \%$

$\%$ Additional width $=\left(\frac{1.94-1.2}{1.2}\right) * 100=61.58 \%$

Based on the hydraulic calculation of the result drainage capacity of existing system were checked and presented in Table 8 to compare with proposed discharges described in the methodology part subtracted existing discharge from the proposed this step is important know over flow peak (excess discharge) for each catchments and for this over flow peak discharge calculate additional depth and width to control the over flow. The existing condition drainage channel depths of catchments 6,7 and 8 Increase by $68.40 \%, 160.20 \%$ and $121.07 \%$; and the widths by $55.44 \%, 116.83 \%$ and $100.98 \%$, respectively, and the Design discharge was also $9.29 \mathrm{~m}^{3} / \mathrm{s}$, $16.47 \mathrm{~m}^{3} / \mathrm{s}$ and $9.13 \mathrm{~m}^{3} / \mathrm{s}$ respectively as described in the above Table 9. 
TABLE 8. Current capacity of the drainage systems of Alamata town

\begin{tabular}{|c|c|c|c|c|c|c|c|c|c|}
\hline Lable & $\begin{array}{c}\text { Normal } \\
\text { Depth (m) }\end{array}$ & $\begin{array}{c}\text { Bottom } \\
\text { Width (m) }\end{array}$ & $\begin{array}{c}\text { Channel } \\
\text { Slope }(\mathbf{m} / \mathbf{m})\end{array}$ & $\begin{array}{c}\text { Flow Area } \\
\qquad\left(\mathbf{m}^{2}\right)\end{array}$ & $\begin{array}{l}\text { Roughness } \\
\text { Coefficient }\end{array}$ & $\begin{array}{c}\text { Wetted } \\
\text { Perimeter }(\mathbf{m})\end{array}$ & $\begin{array}{l}\text { Hydraulic } \\
\text { Radius (m) }\end{array}$ & $\begin{array}{l}\text { Velocity } \\
(\mathrm{m} / \mathbf{s})\end{array}$ & $\begin{array}{c}\text { Discharge } \\
\left(\mathbf{m}^{3} / \mathbf{s}\right)\end{array}$ \\
\hline SC-1 & 0.60 & 1.20 & 0.02000 & 0.72 & 0.015 & 2.40 & 0.30 & 4.23 & 3.04 \\
\hline $\mathrm{SC}-2$ & 0.60 & 1.30 & 0.01500 & 0.78 & 0.015 & 2.50 & 0.31 & 3.76 & 2.93 \\
\hline SC-3 & 0.30 & 0.60 & 0.01400 & 0.18 & 0.015 & 1.20 & 0.15 & 2.23 & 0.40 \\
\hline SC-4 & 0.50 & 1.00 & 0.01400 & 0.50 & 0.015 & 2.00 & 0.25 & 3.13 & 1.57 \\
\hline SC-5 & 0.50 & 1.20 & 0.01500 & 0.60 & 0.015 & 2.20 & 0.27 & 3.43 & 2.06 \\
\hline SC-6 & 0.50 & 1.20 & 0.01800 & 0.60 & 0.015 & 2.20 & 0.27 & 3.76 & 2.26 \\
\hline SC-7 & 0.50 & 1.10 & 0.01500 & 0.55 & 0.015 & 2.10 & 0.26 & 3.34 & 1.84 \\
\hline SC-8 & 0.50 & 1.10 & 0.01100 & 0.55 & 0.015 & 2.10 & 0.26 & 2.86 & 1.57 \\
\hline
\end{tabular}

TABLE 9. Existing, proposed, additional depth and width results

\begin{tabular}{|c|c|c|c|c|c|c|c|c|}
\hline \multicolumn{4}{|c|}{ Existing Condition } & \multicolumn{5}{|c|}{ Proposed Condition } \\
\hline Sub-Catchment & $\begin{array}{l}\text { Depth } \\
\text { (m) }\end{array}$ & $\begin{array}{l}\text { Width } \\
\text { (m) }\end{array}$ & $\begin{array}{l}\text { Existing Discharge } \\
\qquad\left(\mathrm{m}^{3} / \mathrm{s}\right)\end{array}$ & $\begin{array}{c}\text { Design Discharge } \\
\left(\mathrm{m}^{3} / \mathbf{s}\right)\end{array}$ & $\begin{array}{l}\text { Depth } \\
\text { (m) }\end{array}$ & $\begin{array}{l}\text { Width } \\
\text { (m) }\end{array}$ & $\begin{array}{l}\text { \% Additional } \\
\text { Depth }\end{array}$ & $\begin{array}{l}\text { \% Additional } \\
\text { Width }\end{array}$ \\
\hline SC-1 & 0.60 & 1.20 & 3.04 & 8.69 & 0.97 & 1.94 & 61.58 & 61.58 \\
\hline $\mathrm{SC}-2$ & 0.60 & 1.30 & 2.93 & 7.71 & 0.98 & 1.96 & 63.09 & 50.55 \\
\hline $\mathrm{SC}-3$ & 0.30 & 0.60 & 0.40 & 8.05 & 1.01 & 2.02 & 235.86 & 235.86 \\
\hline SC-4 & 0.50 & 1.00 & 1.57 & 8.56 & 1.01 & 2.01 & 101.13 & 101.13 \\
\hline SC-5 & 0.50 & 1.20 & 2.06 & 8.37 & 1.02 & 2.03 & 103.14 & 69.28 \\
\hline SC-6 & 0.60 & 1.30 & 2.26 & 9.29 & 1.01 & 2.02 & 68.40 & 55.44 \\
\hline SC-7 & 0.50 & 1.20 & 1.84 & 16.47 & 1.30 & 2.60 & 160.20 & 116.83 \\
\hline SC-8 & 0.50 & 1.10 & 1.57 & 9.13 & 1.11 & 2.21 & 121.07 & 100.98 \\
\hline
\end{tabular}

\section{Best management paractices (BMPs)}

If Gra-kahsu Mountain were fully covered by forest the value of run-off coefficient " $\mathrm{C}$ " would decrease, this allows flood to infiltrate in to the soil instead of flood generation. Applying different Structural measures of BMPs like terraces, in the Mountain, retaining walls on the river banks like gabion, detention systems, infiltration controls, Porous Pavement Systems and Gabion. Non-structural BMPs that are recommended to control the storm water from the Mountain are; Reduce Man-made impacts, Grassed Swales and covering the mountain with vegetation, area ex closure, gully treatment.

\section{CONCLUSIONS}

The existing drainage system has extensive defects and requires immediate rehabilitation or reconstruction, and also maintaining major drainage works. There is inadequate and low coverage of drainage system coupled with poor physical condition and in electiveness of drainage system development in the town. Capacities of most of the drainage system can't handle the current runoff that flows over the area. The design capacity of the catchments of the town was calculated by taking the intensity for 25-year return period from the IDF and was determined by rational formula. This discharge was also compared with existing discharge of the town was determined from the measured depth and width of the storm water drainage channel for all sub catchments of the town. Then for this existing and design discharge drainage size (channel depth and width) was determine. The existing condition drainage channel depths of catchments 6,7 and 8 Increase by $68.40 \%, 160.20 \%$ and $121.07 \%$; and the widths by $55.44 \%$, $116.83 \%$ and $100.98 \%$, and the design discharge was also $9.29 \mathrm{~m}^{3} / \mathrm{s}, 16.47 \mathrm{~m}^{3} / \mathrm{s}$ and $9.13 \mathrm{~m}^{3} / \mathrm{s}$, respectively.

\section{ACKNOWLEDGMENTS}

I would like to thank National Meteorological Service Agency, Ministry of Agriculture, Ministry of Water, Irrigation and Electricity Addis Ababa, Ethiopia and Alamata town municipality, for their help in providing me with the necessary research data.

\section{REFERENCES}

1. Adugna, D., Lemma, B., Jensen, M.B. and Gebrie, G.S., 2019. Evaluating the hydraulic capacity of existing drain systems and the management challenges of stormwater in Addis Ababa, Ethiopia. Journal of Hydrology: Regional Studies, 25, pp.1-15.

2. Chaudhuri, K., 2018. Study of storm and sewer drains for rajarhat (ward no 4) in west bengal using sewergems software. Thesis for Master of Engineering in Water Resources and Hydraulic Engineering, Jadavpur 
University, India.

3. Noel, P., and Shah, Jagruti., 2019. Critical Review on Smart Systems adopted in Stormwater Drainage Design. Global Research and Development Journal, 4(9), pp.125-127.

4. Pawar, P., Pawar, R.P., Shende, U.B. and Kanoje, P., 2018. Storm Water Management at Approach Road Miet Bhandara. International Research Journal of Engineering and Technology, 5(9), pp.588-594.

5. Patel, K., Patel, K., Patel, R., Trivedi, K. and Patel, D.M., 2017. Storm Water Drainage for Underpass. International Journal for Innovative Research in Science \& Technology, 3(9), pp.23-29.

6. Patel, K.H. and Bhatt, B.V., 2017. Analyses of two existing stormwater drainage lines of surat in west zone using bentley stormcad. Journal of Emerging Technologies and Innovative Research, 4(5), pp. 42-45.

7. Thiagarajan, M., Newman, G. and Van Zandt, S., 2018. The Projected Impact of a Neighborhood-Scaled Green-Infrastructure Retrofit. Sustainability, 10(10), pp.1-13.

8. Nora, M.B. and Reddy, K.N.S., 2018. Performance Assessment of Road Drainage Systems of Burayu Town, Oromia Region, Ethiopia. International Journal of Research in Engineering and Management,
2(2), 40-55.

9. Subramanian, T.S., Cheyapalan, T., Selvaraj, T. and Mariappan, V.N., 2014. Mapping Storm Water Sewer System and using GIS. Journal of Advanced Research in Civil and Environmental Engineering, 1(3\&4), pp.23- 32 .

10. Fagan, C., 2015. Introduction to Bentley FlowMaster CE 365K, Hydraulic Engineering Design. http://www.ce.utexas.edu/prof/ maidment/CE365KSpr15/Bentley/FlowMaster.pdf.

11. Subramanya, K., 2013. Engineering Hydrology. 4th Edition, Tata McGraw-Hill Education.

12. Ethiopian Roads Authority, 2013. Drainage Design Manual. Federal Democratic Republic of Ethiopia.

13. Chow, V.T., 1964. Handbook of applied hydrology.McGraw- Hill Book Company International Editions.

14. Desai, M. and Patel, J.N., 2016. An Advanced GIS based Storm Water Drainage Networking Design for Bhimrad Area of Surat City (India). International Journal of Earth Sciences and Engineering, 9(3), pp.221-228. 